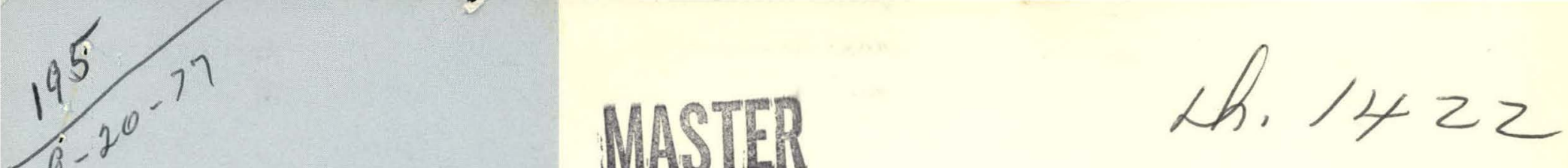

\title{
DETERMINATION OF PERCENT NITROGEN IN SILICON NITRIDE
}

L. D. Keele

\section{OAK RIDGE Y-12 PLANT}

OAK RIDGE. TENNESSEE

prepared for the U.S. ENERGY RESEARCH AND DEVELOPMENT ADMINISTRATION under U.S. GOVERNMENT Contract W-7405 eng 26 


\section{DISCLAIMER}

This report was prepared as an account of work sponsored by an agency of the United States Government. Neither the United States Government nor any agency Thereof, nor any of their employees, makes any warranty, express or implied, or assumes any legal liability or responsibility for the accuracy, completeness, or usefulness of any information, apparatus, product, or process disclosed, or represents that its use would not infringe privately owned rights. Reference herein to any specific commercial product, process, or service by trade name, trademark, manufacturer, or otherwise does not necessarily constitute or imply its endorsement, recommendation, or favoring by the United States Government or any agency thereof. The views and opinions of authors expressed herein do not necessarily state or reflect those of the United States Government or any agency thereof. 


\section{DISCLAIMER}

Portions of this document may be illegible in electronic image products. Images are produced from the best available original document. 
Reference to a company or product name does not imply approval or recommendation of the product by Union Carbide Corporation or the U.S. Energy Research and Development Administration to the exclusion of others that may meet specifications.

Printed in the United States of America. Available from National Techical Inforhation Service

U.S. Department of Commerce

5285 Port Royal Road, 8 płingfield, Virginia 22161

Price: Printed Copy $\$ 3.50$. Microfiche $\$ 3.00$

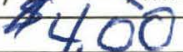

This report was prepared as an account of work sponsored by the United States Government. Neither the United States nor the Energy Research and Development Administration, nor any of their employees, nor any of their contractors, subcontractors, or their employees, makes any warranty, express or implied, or assumes any legal liability or responsibility for the accuracy, completeness or usefulness of any information, apparatus, product or process disclosed, or represents that its use would not infringe privately owned rights. 
Distribution Category: UC-4

\title{
DETERMINATION OF PERCENT NITROGEN IN SILICON NITRIDE
}

\author{
L. D. Keele
}

Plant Laboratory Department

Y-12 Product Certification Division

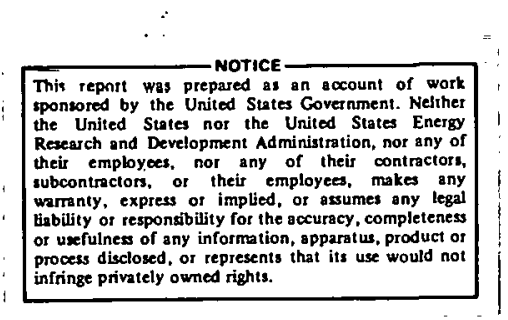

Oak Ridge Y-12 Plant

P. O. Box Y, Oak Ridge, Tennessee 37830

Prepared for the US Energy Research and Development Administration Under US Gonvernment Contrạt W-7405-eng-26 


\begin{abstract}
Percent nitrogen in samples of silicon nitride can be determined by an analytical procedure that first uses a pyrohydrolysis setup to produce an ammonia-type nitrogen solution. Next, the solution is condensed and trapped in a one-molar sulfuric acid solution which is then transferred to a modified Kjeldahl apparatus. Finally, the distillate is trapped in a boric acid solution and titrated, using a mixed indicator. In 12 determinations on a commercial grade of silicon nitride, the nitrogen content was found to be $38.13 \pm 0.84 \mathrm{wt} \%$.
\end{abstract}


CONTENTS

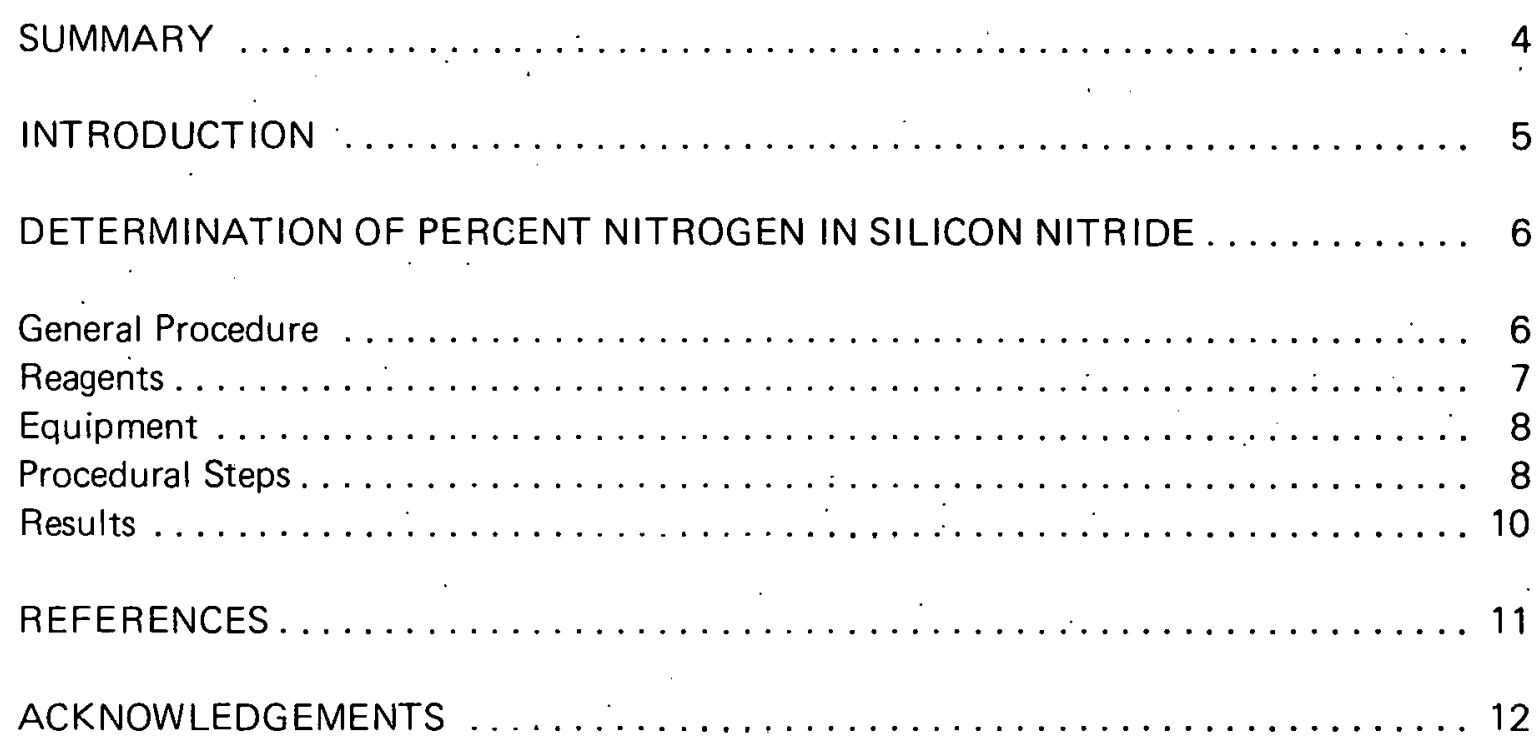




\section{SUMMARY}

In the analysis of silicon nitride for percent nitrogen, two different apparatuses were used. The first apparatus was a pyrohydrolysis setup used to fuse the sample with lithium hydroxide (anhydrous powder) at $800^{\circ} \mathrm{C}$. At the same time, steam was passed over the sample. The resulting ammonia-type nitrogen and a slight amount of contamination of lithium hydroxide were condensed and trapped. in a one-molar solution of sulfuric acid. Next, the distillate was transferred to a one-liter round-bottom boiling flask, then connected to a modified Kjeldahl apparatus. Finally, the solution was made alkaline with sodium hydroxide, heat was applied to the flask, and the resulting distillate was trapped in a boric acid solution which, in turn, was titrated with one-tenth normal hydrochloric acid solution, using a mixed indicator. In 12 determinations on a commercial grade of silicon nitride, the nitrogen content was found to be $38.13 \pm 0.84$ wt \%. 


\section{INTRODUCTION}

In general, any available analytical method for determining the nitrogen content of silicon nitride poses a difficult problem. Some of the methods, such as fusion with sodium carbonate, using such oxidizing agents as sodium nitrite or potassium persulfate, give high blanks and low results. ${ }^{1-4} \mathrm{~A}$ technique for dissolving most of the nitrides, using tin chloride and phosphoric acid, would dissolve only a small portion of the silicon nitride. ${ }^{1} \mathrm{~A}$ sealed-tube method was tried which uses phosphoric acid with oxidizing agents and mixtures of different acids, but this method has met with little success in the decomposition of silicon nitride. ${ }^{3}$

Because these methods were found to be unreliable, a method has been developed at the Oak Ridge Y-12 Plant (a) which uses alkaline compounds as a flux and a pyrohydrolysis apparatus for decomposing the silicon nitride. Since lithium hydroxide anhydrous powder is granular and has a relatively high melting point, it was selected in place of either sodium or potassium hydroxide.

(a) Operated by the Union Carbide Corporation's Nuclear Division for the US Energy Research and Develupment Administration. 


\section{DETERMINATION OF PERCENT NITROGEN IN SILICON NITRIDE}

\section{GENERAL PROCEDURE}

A silicon nitride sample is weighed and placed on a layer of lithium hydroxide (anhydrous powder) in a nickel boat, then a second layer of lithium hydroxide is added to cover the sample. (Total weight of the lithium hydroxide is about five grams.) The sample is placed in a quartz liner, then the liner is inserted into a quartz reaction tube that is connected to a steam generator and a spiral condenser (Figure 1). Heat is applied with two clamshell

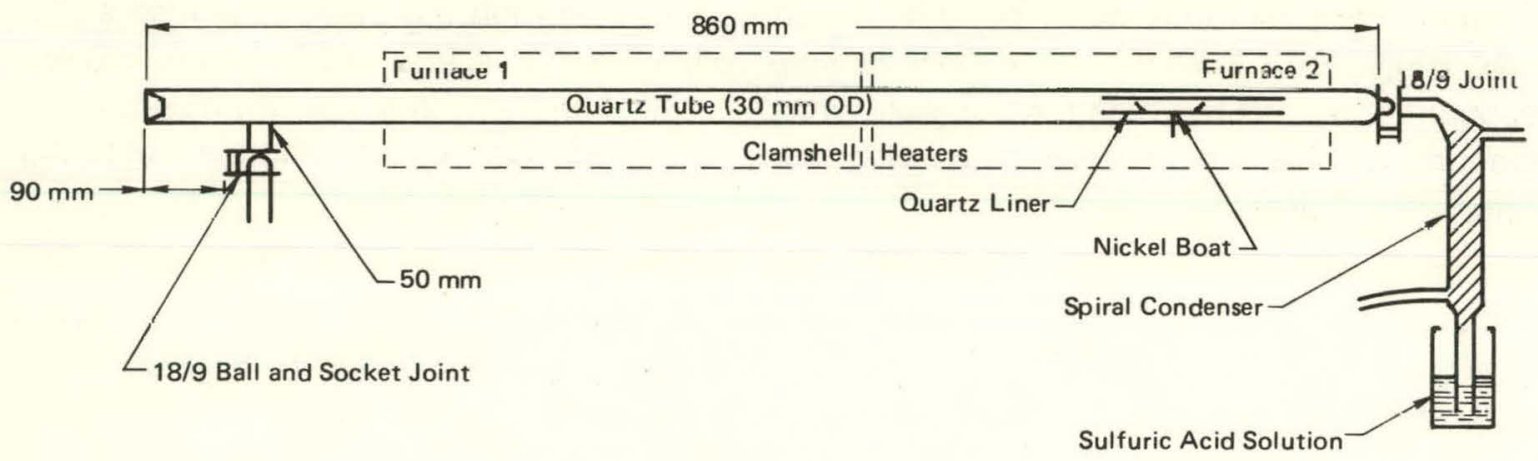

Figure 1. QUARTZ REACTION TUBE WITH STEAM GENERATOR AND SPIRAL CONDENSER.

furnaces (Figure 2). (The temperature of the furnaces is controlled by two heavy-duty Variacs.) Initially, the temperature of the first furnace is set at $850^{\circ} \mathrm{C}$, while the second furnace is set at $350^{\circ} \mathrm{C}$. The liner and sample are placed in the second furnace area and the temperature of this furnace is increased slowly to $800 \mathrm{C}$ C. At the same time, steam is passed over the sample. The ammonia-type nitrogen that is released during the fusion is condensed, then trappod in a one-molar sulfurir arid solution. (This solution is also contaminated slightly with lithium hydroxide.) After distilling approximately 400 milliliters, the distillate is transferred to a $1000-\mathrm{ml}$ round-bottom boiling flask, the flask is connected to a modified Kjeldahl

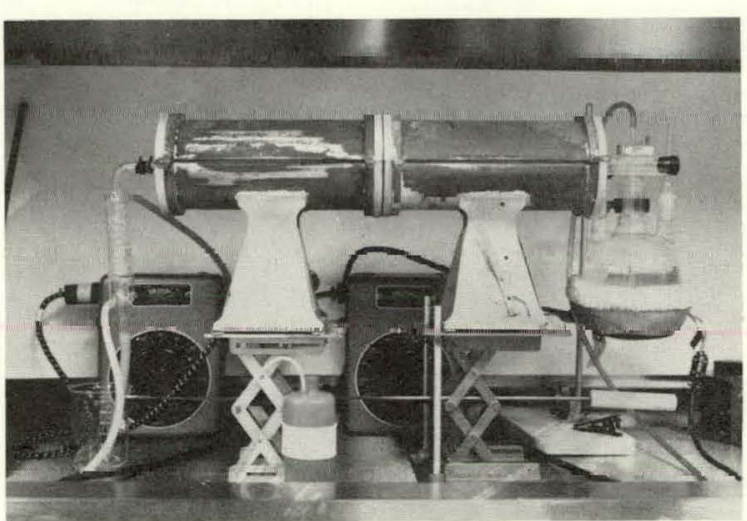

Figure 2. TWO CLAMSHELL FURNACES. apparatus (Figure 3), the solution is made alkaline with $50 \%$ sodium hydroxide, and heat is applied to the flask, using a heating mantle. The ammonia distillate is allowed to react with a $2 \%$ boric acid solution $(0.1 \underline{\mathrm{N}})$ to a faint pink endpoint. In 12 determinations on a commercial-grade silicon nitride, the nitrogen content found by this procedure was $38.13 \pm 0.84$ wt $\%$. 


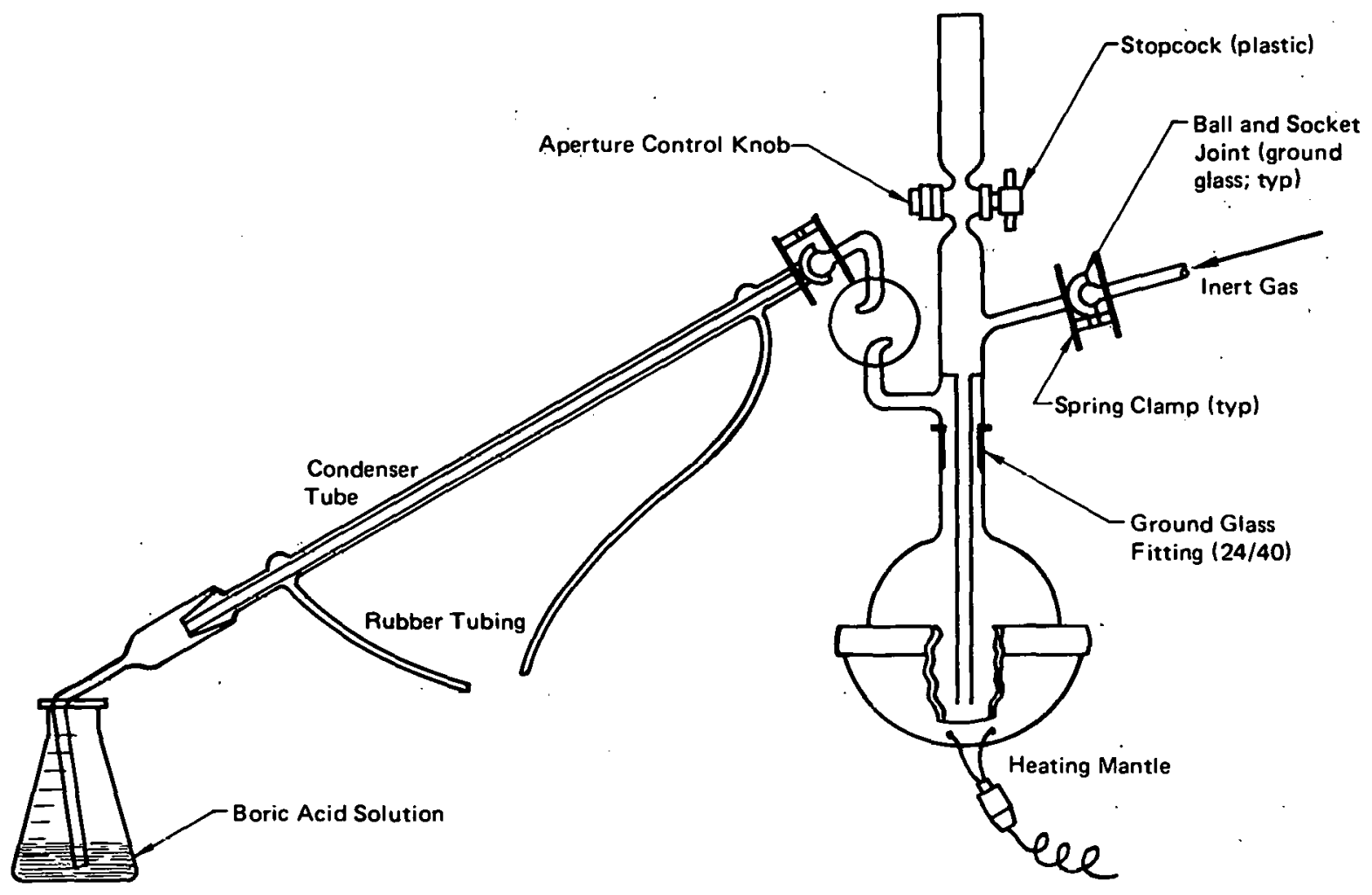

Figure 3. MODIFIED K.JELDAHL APPARATUS.

\section{REAGENTS}

The following reagents are required in this analytical procedure:

Sulfuric acid (one-molar solution)

Hydrochloric acid (one-tenth-normal solution)

Boric acid (two-percent solution ${ }^{(b)}$ )

Methyl red (one-terllh-percent solution)

Bromcresol green (one-tenth-percent solution)

Sodium hydroxide (fifty-percent solution)

Lithium hydroxide (anhydrous powder)

Phenolphthalein (one-percent solution)

Helium (used as the sweep gas)

(b) The boric acid solution was made by dissolving 40 grams of boric acid in 1960 milliliters of deionized water, then adding 2 milliliters of a $0.1 \%$ methyl red solution and 10 milliliters of a $0.1 \%$ bromcresol green solution. The final volume was then made to two liters. 


\section{EQUIPMENT}

The following items of equipment are utilized in this procedure:

Furnaces (2), clamshell (range to $1000^{\circ} \mathrm{C}$ )

Boat, nickel (90 mm long $\times 16 \mathrm{~mm}$ wide, $12 \mathrm{~mm}$ deep)

Variac control (for the heating furnace)

Variac control (for the heating mantle)

Heating mantle (one-liter size)

Heating mantle (two-liter size)

Boiling flask (one-liter size, with a $24 / 40$ ground-glass fitting)

Distilling flask, three-neck (two liters: 5 -sides: 24/4n, center: 15/60)

Adapter (24/40 $\$$ male joint, tapered to $18 / 9$ ball joint)

Pyrohydrolysis apparatus (connected to a steam generator and a condenser)

Distilling apparatus (modified Kjeldahl design, with condenser)

Jacks (laboratory)

Flask, Erlenmeyer (large mouth, $500 \mathrm{ml}$ )

Beaker $(800 \mathrm{ml})$

Burette $(50 \mathrm{ml})$

Stirrer, magnetic (electric driven)

Stirring bar (sealed in Teflon)

Stopper, rubber (size 6)

Reaction tube, quartz (ID, $27 \mathrm{~mm}$ : $\Omega D, 30 \mathrm{~mm}$; length, $860 \mathrm{~mm}$ )

Liner, quartz (ID, $22 \mathrm{~mm}$; OD, $25 \mathrm{~mm}$; length. $200 \mathrm{~mm}$ )

\section{PROCEDUAAL GTEPS}

I he tollowing steps describe the analytical procedure:

1. Weigh 100 milligrams of silisnn nitrịde.

2. Transfer the silicon nitride sample to a nickel boat which has a layer of lithium hydroxide.

3. Cover the silicon nitride sample with a second layer of lithium hydroxide. (Total weight of the lithium hydroxide is 4 to 5 grams.)

4. Introduce the nickel boat containing the sample into a quartz liner, then insert the quartz liner into the quartz reaction tube and place the assembly in the second furnace area and heat to $350^{\circ} \mathrm{C}$. 
5. Connect a steam generator to the reaction tube.

6. Connect a spiral condenser with a rubber tip to the quartz reaction tube and turn on the cooling water.

7. Add 50 milliliters of one-molar sulfuric acid solution to an 800-milliliter beaker.

8. Place the 800-milliliter beaker under the condenser, with the rubber tip just below the surface of the sulfuric acid solution.

9. Place the rubber stopper in the quartz reaction tube.

10. Regulate the temperature of the initial furnace to $850^{\circ} \mathrm{C}$.

11. Regulate the temperature of the steam generator so that 5 milliliters of distillate are collected per minute.

12. Increase the temperature of the second furnace to $800^{\circ} \mathrm{C}$.

13. Collect between 300 to 400 milliliters of distillate.

14. Transfer the distillate to a one-liter round-bottom boiling flask having a $24 / 40$ tapered-joint fitting.

15. Rinse the 800-milliliter beaker with deionized water and add the contents to the flask.

16. Connect the flask and condenser to a modified Kjeldahl apparatus.

17. Turn on the cooling water to the condenser.

18. Add 50 milliliters of boric acid solution to a 500-milliliter large-mouth Erlenmeyer flask.

19. Place the condenser tip just below the surface of the boric acid solution.

20. Add the 50 percent sodium hydroxide solution to the boiling flask through a stopcock to a phenolphthalein endpoint.

21. Apply lieat to the boiling flask with a heating mantle, sontrolled with a Variac.

22. Introduce a floviv of inert gas (helium) as a sweep gas.

23. Increase the temperature of the solution to the boiling point.

24. Collect approximately 300 milliliters of condensate in 50 milliliters of the boric acid solution. 
25. Titrate the boric acid solution to a pink endpoint with one-tenth-normal hydrochloric acid solution.

26. Calculate the percent nitrogen by the equation:

$$
\% \mathrm{~N}=\frac{(\mathrm{ml} \mathrm{HCl}-\text { blank }) \times \underline{\mathrm{N}} \times \text { mequiv } \times \text { wt } \mathrm{N} \times 100}{\text { wt sample }(\mathrm{g})}
$$

\section{RESULTS}

Table 1 reports the results of 12 determinations for percent nitrogen content on a commercial grade of silicon nitride.

These accumulated data were statistically evaluated and yielded an absolute limit of error of $\pm 0.24 \%$ (0.95), which is equivalent to an absolute limit of error of $\pm 0.84 \%$ (0.95) for a single determination.

\begin{tabular}{cccc}
\multicolumn{5}{c}{ Table 1} \\
\multicolumn{4}{c}{$\begin{array}{c}\text { DETERMINATION OF NITROGEN IN SILICON } \\
\text { NITRIDE }\end{array}$} \\
$\begin{array}{c}\text { Sample } \\
\text { Number }\end{array}$ & $\begin{array}{c}\text { Nitrogen } \\
(\%)\end{array}$ & $\begin{array}{c}\text { Sample } \\
\text { Number }\end{array}$ & $\begin{array}{c}\text { Nitrogen } \\
(\%)\end{array}$ \\
\hline 1 & 38.354 & 7 & 38.257 \\
2 & 37.922 & 8 & 38.008 \\
3 & 38.305 & 9 & 38.060 \\
4 & 38.144 & 10 & 38.069 \\
5 & 38.031 & 11 & 38.189 \\
6 & 37.946 & 12 & 38.385 \\
\hline
\end{tabular}




\section{REFERENCES}

1. Bollman, D. H.; "Rapid Technique for Dissolution of Nitrides", Analytical Chemistry, 44, p 887 (1972).

2. Erickson, S. L. and Conrad, F. J.; Determination of Boron in Boron Nitride, SC-RR-710073; Sandia Laboratories, Albuquerque, New Mexico (1971).

3. Keele, L. D.; Determination of Nitrogen in Boron Nitride, Y-1718; Union Carbide Corporation-Nuclear Division, Oak Ridge Y-12 Plant, Oak 'Ridge, Tennessee; May 11 , 1970.

4. Kriege, O. H.; The Analysis of Refractory Borides, Carbides, Nitrides, and Silicates, LA 2306; Los Alamos Scientific Laboratory, Los Alamos, New Mexico (1959). 


\section{ACKNOWLEDGEMENTS}

The author would like to thank L. M. Steckel for his suggestions and T. H. Barton, Jr for his comments during the preparation of this report. 


\section{Distribution}

Energy Research and Development

Paducah Gaseous Diffusion Plant

Administration - Oak Ridge

Hickman, H. D.

Bewley, H. D.

Leed, R. E.

Zachry, D. S., Jr

\section{Oak Ridge Gaseous Diffusion Plant}

Stief, S. S.

Wilcox, W. J., Jr

\section{Oak Ridge Y-12 Plant}

Barton, T. H., Jr Bernander, N. K. Briscoe, O.W.

Burditt, R. B.

Burkhart, L. E.

Duggan, H. G.

Fraser, R. J.

Green, L. A.

Jamison, R. L., Jr

Jones, F. W.

Kahl, K. G.

Keele, L. D. (10)

Keith, A.

Killeen, O. P.

Kite, H. T.

Martin, W. R./Googin, J. M.

Mason, D. L./Schreyer, J. M.

McLendon, J. D.

Mills, J. M., Jr

Phillips, L. R.

Rhew, J. C.

Schmitt, C. R.

Smlth, H. F., Ji

Sinith, R. D.

Tewes, W. E.

Thomason, J. C.

Tucker, W. O.

Y 12 Central Files (master copy)

$Y-12$ Central Files (route copy)

$Y-12$ Cenilial Files $(Y-12 R C)$

Y.12 Central Files (5)

In addition, this report is distributed in accordance with the Category UC-4, Chemistry, as given in the USERDA StandarU Distribution Licts for Unclassified Scientific and Technical Reports, TID 4500. 